\title{
Pieśni rozpaczy w czasach pogardy Wokół cyklu poetyckiego Márciustól márciusig Istvána Vasa
}

Abstract: Kinga Piotrowiak-Junkiert, Pieśni rozpaczy w czasach pogardy. Wokół cyklu poetyckiego Márciustól márciusig Istvána Vasa (Songs of Despair in Times of Contempt. On the Poetic Cycle of Márciustól Márciusig by István Vas). "Poznańskie Studia Slawistyczne" 17. Poznań 2019. Publishing House of the Poznań Society for the Advancement of the Arts and Sciences, Adam Mickiewicz University, pp. 209-220. ISSN 2084-3011.

The article offers an interpretation of the poetic cycle Od marca do marca [From March to March] by István Vas, a Hungarian poet and writer of Jewish origin. The author treated each of his poems as a notebook, where he recorded his reflections on the situation of Hungarian Jews, the human condition, the siege of Budapest, etc. For Vas, each piece is a separate testimony to the time of the war. The entire cycle is steeped in irony and a harsh judgement of the society's moral fall. Vas wrote his poems during the period of Nazism but published them during the communist regime, when he wanted to answer a question about the role of art in the process of recovering historical memory, and whether a literary text could offer protection from the hostile reality.

KeYwords: István Vas; Hugarian Jewish literature; II World War in Hungary; Siege of Budapest

Życiorys Istvána Vasa (1910-1991) splótł się z najważniejszymi wydarzeniami XX wieku na Węgrzech: I i II wojną światową, traumą trianońską, ustawami żydowskimi, pracami przymusowymi (munkaszólgálat), komunizmem i transformacją ustrojową. Postawa światopoglądowa poety ewoluowała: najpierw, jako przedstawiciel trzeciego pokolenia zasymilowanych Żydów węgierskich (Fenyves, 2010), buntował się przeciwko patrycjuszowskiej generacji millenarystycznej stolicy, z której się wywodził, ale później, mimo lewicowych poglądów i popierania filozofii marksistowskiej, poszukiwał wiary i w 1938 roku przeszedł na katolicyzm, co nie przeszkodziło mu jednak pełnić ważnych funkcji państwowych w Ministerstwie Spraw Wewnętrznych w czasach rządów Mátyasa Rákosiego 
(po 1945 roku). Romans z władzą trwał krótko, bo w 1953 roku Vas został na własną prośbę usunięty z Partii Komunistycznej.

W powieści autobiograficznej Azután pisał:

Narzekałem na moją sytuację pisarską, zwłaszcza na to, że nigdzie nie należę. Uważają mnie za przedstawiciela nurtu ludowo-miejskiego, ci z kręgu miejskiego mają mnie za renegata. Bliższy krąg moich przyjaciół to w większości krąg Argonautów ${ }^{1}$, który znalazł dla siebie schronienie w gminie żydowskiej i organizował odczyty literackie w sali Goldmarka, wydał antologię, słowem wiódł życie duchowe (Vas, 1990, $286)^{2}$.

Istotnie, próba przyporządkowania Vasa do jakiegokolwiek nurtu czy grupy byłaby obciążona ryzykiem nieuchronnej porażki, bo pisarz chadzał zawsze własnymi drogami, stawiając sobie za cel pionierskie wyzwania, i walczył o niezależność pisarską bez względu na cenę, jaką przyszło mu za to płacić. „Nie znamy wielu takich poetów we współczesnej literaturze - pisał István Fenyő - którzy w czasach wystawiających ludzi na próbę równie mocno strzegliby indywidualizmu i suwerenności artystycznej" (Fenyő, 1976, 8). Z jednej strony Vas należał do elitarnego grona twórców proeuropejskiego, prozachodniego czasopisma „Nyugat”, a z drugiej strony na łamach lewicującego periodyku „Dokumentum” i „Munka” współpracował z ich twórcą, awangardystą Lajosem Kassákiem.

Godził w swoim światopoglądzie, propagujące otwartość na nowe języki sztuki i estetykę, poglądy liberalne z fascynacją leninizmem. Balansowanie między różnymi obozami wynikało u Vasa z mozaikowej tożsamości, w której siła jej poszczególnych komponentów nie pozwalała na radykalne odcinanie się od zaplecza rodzinnego i żydowskiego pochodzenia, stanowiących niewątpliwie podstawę literackiego tworzywa. Co ciekawe, w „Nyugacie” (podobnie jak Miklós Radnóti, Antal Szerb i György Sárközi) Vas należał do „dystansujących się od wiary żydowskiej neofitów”, zwanych także „,neokatolikami” (Köbányai, 2014, 228). A publikując w czasopismach Kassáka potwierdził swoją przynależność

\footnotetext{
${ }^{1}$ Klub Argonautów (Argonáuták) - inicjatywa pisarska, translatorska i wydawnicza mająca na celu prezentowanie i publikowanie tekstów kultury starożytnej i jej interpretacji. Grupa zawiązała u progu II wojny światowej. Należał do niej m.in. wybitny poeta i przyjaciel Vasa, Miklós Radnóti (1909-1944).

${ }^{2}$ Wszystkie thumaczenia, jeśli nie podaję inaczej, są mojego autorstwa (K.P.-J.).
} 
do budapeszteńskich elit żydowskich, wykazywał żywe zainteresowanie marksizmem i świetną znajomość leninizmu.

Artysta już w młodości radykalnie wyparł się przynależności do klasy zamożnych mieszczan, której status potwierdzało spędzanie wakacji w austriackim kurorcie Bad Gastein i jadanie w restauracji Hangli, pisał o sobie: „nie jestem tym, kim się urodziłem” (Vas, 1987, 403) i dodawał: „nie stałem się tym, do czego byłem predestynowany, czyli nie wyrosłem na rozpieszczone, żydowskie dziecko z dzielnicy Lipótvár. Człowiek niesie jednak z sobą swoją rodzinę nawet wtedy, kiedy ją neguje" (Vas, 1987, 403). Badacz twórczości Vasa, László Sturm, widział w tym znak rozpoznawczy pisarza:

Bycie Węgrem i bycie Żydem, wiara i ateizm, prawicowość i lewicowość (i niezliczone ich odgałęzienia), pozostanie w kraju i dłuższe wyjazdy zagraniczne, życiorys wykreowany przez poetę $\mathrm{i}$ ten wymuszany przez ojca to tylko niektóre $\mathrm{z}$ jego ówczesnych dylematów (Sturm, 2017, 7).

Podwójna tożsamość, choć wiązała się z koniecznością ciągłego dookreślania się, sprawiła również, że Vas miał kontakt z twórcami reprezentującymi najróżniejsze fronty intelektualne, a co za tym idzie światopoglądowe. Kształtował więc w sposób równoległy swoją wrażliwość konserwatysty i lewicowca, stał się dzięki temu ważną osobą dla środowisk reprezentujących różne fronty polityczne.

Jedną z najtrudniejszych prób, weryfikującą system wartości i wrażliwość artystyczną Vasa, był czas wojny i lata powojenne. W przeciągu niespełna roku (od marca 1944 do marca 1945) zginęła większość jego przyjaciół, w tym Miklós Radnóti, z którym łączyła go niezwykle silna więź i wspólne projekty translatologiczne. Vas przeżył, ponieważ był zwolniony z wywózki na roboty przymusowe dzięki zaświadczeniu od psychiatry, który uznał go za niepoczytalnego. W czasie oblężenia Budapesztu, po dojściu do władzy strzałokrzyżowców, ukrywał się wraz z późniejszą drugą żoną, Mariką Kutni, w domu Gézy Ottlika³. W 1976 roku z rozmowie z Pálem Rézem wspominał:

To on, bez cienia wahania, żeby nie powiedzieć z nonszalancją, niemal z frywolną lekkością zaproponował, żebym, bo jakżeby inaczej, poszedł do niego, a muszę do-

${ }^{3}$ Géza Ottlik (1912-1990) - jeden z najważniejszych pisarzy węgierskich XX wieku, autor legendarnej powieści inicjacyjnej, Iskola a határon (Ottlik, 1973). 
dać, że nie miałem papierów, bo do tej pory ich nie potrzebowałem, liczyłem, że będę wyjątkiem. I bez żadnego dodatkowego ale - a nie jesteście w stanie wyobrazić sobie jakie to było ryzyko - spędziliśmy razem czas oblężenia. Więc najkrócej mogę o nim powiedzieć, że uratował mi życie. Co więcej, ratował mnie na swoją zgubę, bo nie lubił niczego, co robiłem (Réz, 1999, 13).

Wstrząs wywołany wojną, stworzenie trzech gett w stolicy (dużego, małego i międzynarodowego), prześladowania i czystki dokonywane na mieszkańcach żydowskiego pochodzenia, a także egzekucje nad brzegiem Dunaju w kluczowy sposób zmieniły dykcję poetycką Vasa. Teksty poświęcone oblężeniu stolicy, antysemickim atakom i przemianie mentalności węgierskiego społeczeństwa, w odróżnieniu od wcześniejszych utworów, cechowała lapidarność, surowa ironia, a przede wszystkim rezygnacja z estetyzacji, w której poeta się specjalizował.

Vas, podobnie jak inni twórcy węgierscy (w tym Miksa Fenyő, Tibor Déry, József Darvas, Lajos Kassák), postanowił pisać, mimo tragicznych warunków psychicznych i egzystencjalnych ${ }^{4}$. Między 3 grudnia 1944 a 16 marca 1945 prowadził w spiralnym zeszycie w linie, ,pisany tylko dla siebie", dziennik - Ostromnapló (Dziennik oblężenia), z którego ogłosił drukiem jedynie krótkie fragmenty (Vas, 1958, 9-117; 1979, 129-141; 1996, 593-624). Część zapisów wykorzystał w książce Azután (Vas, 1990). Tekst nigdy nie doczekał się pełnego druku, głównie z uwagi na jego zbyt osobisty charakter 5 .

Nie był to jednak jedyny tekst poświęcony wojnie, bo w pierwszym tomie wydanym po wyzwoleniu, Kettős örvény (1947, Podwójny nurt) poeta zamieścił cykl poetycki Márciustól márciusig (Od marca do marca)

${ }^{4} \mathrm{~W}$ dziennikach węgierskich pisarzy wkroczenie Niemców zostało odnotowane z niezwykłym dramatyzmem. Sándor Márai zapisał to wydarzenie graficznie, stawiając grubą, poziomą kreskę po zdaniu „Niemcy zajęli Węgry” (Márai, 2004, 47). István Pius Zimandi, duchowny i legendarny pedagog pisał: „Podenerwowanie, niepokój... Radio milczało. W godzinach południowych i popołudniowych nie nadawało, przewidywano, że będą naloty. Później, zamiast zwykłego programu, grano muzykę poważną" (Zimándi, 2015, 19). Z kolei Simon Kemény przerwał pisanie swojego legendarnego dziennika 18 marca, uznając, że nowa sytuacja kraju nie znajdzie już słów w języku (Kemény, 1987).

${ }^{5}$ Jednym z argumentów przemawiających za odstąpieniem od zamiaru publikacji mogły być względy natury artystycznej - Vas przepracował swoją biografię w dwóch esejach autobiograficznych i w to w nich referował drobiazgowo życie osobiste i zawodowe, począwszy od wspomnień z dzieciństwa (Nehéz szerelem, tom 1 i 2), przez lata wojny (Miért vijjog a keselyü tom 1 i 2), a także czasy powojenne (Azután, tom 1 i 2). 
obejmujący czas między dniem wkroczenia Niemców na Węgry (19 marca 1944 roku), a marcem 1945 roku, kiedy w kraju skończyła się wojna.

Cykl Márciustól... stał się rodzajem lirycznego notatnika, ,wierszowanego dziennika”, jak go określił László Kálnoky (1947, 508), w którym poeta postanowił zmierzyć się z doświadczeniem wojny na kilka różnych sposobów: szukał języka nazywającego graniczność sytuacji węgierskich Żydów, kreował opisy oblężonego miasta, odnosił się do zachowań i światopoglądów różnych grup społecznych (przede wszystkim węgierskiej i żydowskiej), ale także budował spójną strategię samostanowienia poprzez tekst. Vas traktował pisanie jako czynność polegającą na obowiązku definiowania własnej postawy wobec wojny i społeczeństwa, a także wobec nowych czasów. Wiersze powstały równolegle do wydarzeń lub krótko po nich, ostatnie już w czasie powojennego komunizmu, Vas pełnił wówczas funkcje państwowe.

Głębszy namysł nad cyklem należy poprzedzić podkreśleniem kilku ważnych faktów. Zbiór czterdziestu pięciu wierszy poeta postanowił opublikować w czasach kolejnego reżimu, kiedy większość twórców węgierskich żydowskiego pochodzenia była objęta silentium, bowiem stalinowskie Węgry propagowały politykę uciszenia pisarzy żydowskiego pochodzenia i wyeliminowania z debaty publicznej tematu żydowskiego. Decyzja artystyczna Vasa, osobiście zaangażowanego w tworzenie nowego państwa i pragnącego publikować, nosiła więc na sobie znamiona manifestu i pod każdym względem należy doszukiwać się w niej ukrytego przesłania dotyczącego roli i udziału sztuki w procesie odzyskiwania pamięci historycznej.

Przyjrzyjmy się najpierw budowie cyklu i tematom wierszy. Vas, wypowiadając się z punktu widzenia kronikarza, mieszkańca, Węgra i Żyda oraz wdowca opłakuje przede wszystkim nastanie nowej (osobistej i politycznej) rzeczywistości. Przeżywa - w czynności kompulsywnego pisania - żałobę po bliskich ludziach (w tym po zmarłej w 1939 roku na raka mózgu żonie, wybitnej choreografce i tancerce, Eti Nagy), rozpacza nad bombardowanym miastem, wreszcie nad własną tożsamością, która stała się powodem nieustającego lęku o życie. Poetyckie treny Vasa prowadzą czytelnika w wielu kierunkach naraz, łącząc medytacje nad uniwersaliami (kondycją człowieka i jego wartością) i zwyczajnymi problemami jednostki usiłującej przetrwać czas wojny. Przy czym zaznaczyć trzeba, 
że pogłębiona refleksja nad egzystencją szybko przeradza się w koncept budowania intelektualnej zapory, oddzielającej twórcę od nieubłaganego w swym okrucieństwie, ale wciąż postrzeganego z ironią, świata.

W pierwszym z czterdziestu pięciu wierszy cyklu, Peron (Peron), Vas pisze:

\author{
Na stole pyszni się \\ Różowy tulipan. \\ Kiedy wczoraj po południu \\ Zaczął kwitnąć, \\ Pod Hegyeshalom jeszcze stały w ciszy \\ niemieckie oddziały. \\ Niczego nie podejrzewaliśmy. Ale teraz już wiem, \\ Że ten sobotni wieczór był pożegnaniem. \\ Czekam, jakbym szykował się w drogę. \\ $\mathrm{W}$ ręce zaciskam elegancką torbę. \\ Dwujęzyczne nowiutkie wydanie Tacyta. \\ Tłum napiera. Złośliwy gazeciarz krzyczy (Vas, 2000, 209).
}

Poczucie osamotnienia, wielokrotnie opisanego w tomie Kettös örvény, przemienia się w poezję poświęconą uniwersalnej, ludzkiej samotności, bliskiej filozofii preegzystencjalistów. Vas, podobnie jak inni poeci jego czasów, wychowankowie szkoły „Nyugatu” (Babits, Kosztolányi, Márai), pisze o tęsknocie za czasami Tyberiusza, kiedy „śmierć była prosta i niewinna" (Nem a halál), o komorach gazowych i zasypywaniu dołów wapnem, o groteskowym stanie oczekiwania na śmierć (Ancien régime), wreszcie o opustoszałych przestrzeniach miasta: zbombardowanych mostach, wyludnionych ulicach stolicy (Budapest balladája), które stają się sceneriami wojennej codzienności.

Vas nie ma złudzeń, że największą siłą nowych czasów jest świadomość, ale świadomym można być tylko katastrofy. W wierszu Budapest balladája stwierdza: „poeta chwacko rymuje, ale przewraca mu się w trzewiach", bo już tylko on dostrzega upokorzenie Budapesztu, chorobę toczącą ojczyznę i Europę, a zwłaszcza konsekwencje epidemii wywołanej przez bakcyl nienawiści, na którą trzeba znaleźć surowicę (Gyülölet). Poeta ma zadanie, fundamentalne z punktu widzenia dziejów: staje się jasnowidzem, przejmuje od innych obowiązek dawania świadectwa, a ostatecznie także moralnego rozliczenia narodu. W kolejnych wierszach (Április, Független Magyarország) podmiot liryczny zaczyna 
bezwzględnie punktować błędy i winy polityki nazistowskiej oraz węgierskiego społeczeństwa. Vas zmienia się z obserwatora w oskarżyciela, odważnego buntownika domagającego się odzewu, a przede wszystkim poruszenia sumień.

W wierszu Április Vas opisuje jeden z najtragiczniejszych dni w historii budapeszteńskich Żydów - 5 kwietnia 1944, czyli dzień wprowadzenia obowiązku noszenia gwiazdy Dawida:

Kwiecień, dziwaczny żart się zdarzył:

muszę nosić nad sercem gwiazdę żółtą jak kanarek

[...] pod łatą noszę kraj

jego cały, wielki, żółty wstyd (Vas, 2000, 214-215).

Obserwacja pogrążonej w wojnie ojczyzny, prowadzi do poszukiwania metafor pozwalających nazwać nowe emocje w taki sposób, by odpowiednio podkreślić stosunek do rzeczywistości postrzeganej przez widza zatrutego natrętnymi, autodestrukcyjnymi myślami: „siedzę w kawiarni, w kieszeni mam cyjanek. Dlaczego wciąż żyję, sam nie wiem" (Júliusi jegyzetek; Vas, 2000, 225). Kolejne wiersze skrupulatnie odnotowują sceny z życia budapeszteńskich Żydów, o których pisze z prywatnej perspektywy. Kryzys duchowy matki podsumowuje słowami: „nie płacze, czasami się uśmiecha. / Jeszcze nie zamknęli jej w wagonie. Ani Węgrzy, ani Niemcy” (Júliusi jegyzetek; Vas, 2000, 227). Wreszcie stwierdza: „Ci, z których się wywodzę, szykują się na śmierć, pięć lat temu umarła ta, którą kochałem" (Vas, 2000, 228).

W recenzjach poświęconych powojennemu tomowi pojawiły się głosy podkreślające niezwykłą świadomość Vasa przeradzającą się w pesymizm „osiągający najmroczniejsze odcienie” (Kálnoky, 1947, 506), nazwany przez Kálnokyego „,pesymizmem metafizycznym”. Badacz sądził, że poeta „nie ukrywa ani przed innymi, ani przed samym sobą, że instynkt jest silniejszy od rozumu i zrozumienia, a motorem poruszającym świat jest wola" (Kálnoky, 1947, 506). György Lukács dostrzegał w postawie artystycznej Vasa bogate zaplecze filozoficzne, które - jak podejrzewał krytyk - pomogło pisarzowi przetrwać czasy faszyzmu bez uszczerbku dla bardzo wysokich standardów moralnych w świecie, w którym na każdym kroku dostrzegało się i odczuwało „fiasko moralności” (Lukács, 1999, 59). 
Lektura utworów zamykających cykl zaskakuje intensywnością i coraz rozpaczliwiej wyrażanym rozczarowaniem Węgrami. W wierszach podsumowujących kolejne miesiące inwazji niemieckiej, np. w Júliusi jegyzetek (Zapiskach Lipcowych) i Szeptemberi jegyzetek (Zapiskach wrześniowych) Vas konstatuje: „Węgry są siekierą, która nie ma już trzonka. Składają się tylko z ostrza" (Augusztusi jegzyetek; Vas, 2000, 235), a miesiąc później, we wrześniu 1944 roku notuje: „Jesień w barwach czerwieni, ale nie patrzę na nią. Nie piszę i nie tłumaczę” (Vas, 2000, 239) i dodaje: „czy jest ktoś, kto nie nienawidziłby słowa «węgierskie»?" (Szeptemberi jegyzetek; Vas, 2000, 240). Poeta nie ukrywa już, że zna swoją rolę, jego zadanie polega na asystowaniu agonii Węgier. Wskazuje jedyny rym do słowa ojczyzna, którym ma być onomatopeiczny okrzyk „ha, ha” (Vas, 2000, 241). Ojczyzna to przeklęta pułapka, bo Vas wie, że tylko w tym przeklętym miejscu może być poetą. „Węgry - pyta - czy można się do nich przyzwyczaić?”.

Ostatnie tematy cyklu to walka i upadek Warszawy, rozpadanie się kraju, krajobraz polskiej stolicy ze zbombardowanymi mostami. Kiedy zbliża się koniec wojny i wypracowany do perfekcji ,plastyczny, liryczny realizm" (Szigeti) staje się skrajnie wyeksploatowanym narzędziem artystycznego wyrazu, Vas - nieoczekiwanie - zaczyna stylizować wiersze, parafrazuje inicjalne zdanie najstarszego zabytku języka węgierskiego, Halotti beszéd, czyli mowy pogrzebowej. Vas opisuje katastrofę dziejową, architektoniczną, emocjonalną i społeczną węgierskiego społeczeństwa obrazami ironicznie splecionymi z szeroko zakreślonym kręgiem kultury śródziemnomorskiej, wreszcie wiersze stają się wyrafinowanymi formami poetologicznymi. Pojawiają się sonet, elegia, gazela, fraszka i tren, napisane w różnych stopach metrycznych: anapestem, jambem i heksametrem, a ponadto wzbogacające sens utworów dzięki leksykalnym odniesieniom do różnych estetyk wypowiedzi poetyckiej (od węgierskiej idylli oświeceniowej do wierszy ludowych poetów dziewiętnastowiecznych, od starowęgierskich fraz ze średniowiecznych ksiąg pogrzebowych po nowoczesne słownictwo stolicy). Vas wyraża przez to główną ideę wpisaną w los artysty: pisanie, nawet w warunkach dramatycznych, można poprowadzić tak, by stawało się, mimo głębokiego zaangażowania w proces relacjonowania rzeczywistości, drogą do osiągnięcia intelektualnego dystansu. Czas publikacji cyklu pozwala również dostrzec inny ważny szczegół, na stalinowskich Węgrzech w obliczu marginalizacji kwestii żydowskiej, 
prawdę historyczną poznawano wyłącznie dzięki literaturze (najczęściej podziemnej).

Decyzja o włączeniu do tomu cyklu bezkompromisowo obnażającego postawy społeczne i politykę strzałokrzyżowców musiała być umotywowana imperatywem demokratyzacji sztuki, która miała być wspólną dla wszystkich przestrzenią obnażania kłamstw historycznych, prezentowania rzetelnych faktów, oddawania sprawiedliwości uciszonym, a przede wszystkim potępienia świata totalitarnego.

Postawa Vasa jest w cyklu Márciustól márciusig dowodem wybrania narracji obywatelskiej, wypowiadania się na temat uniwersalnych problemów etycznych, wreszcie przyjęcia roli stołecznego kronikarza, zatajającego przed czytelnikiem szczegóły, które znajdziemy w rękopisie Ostromnapló (np. osobiste zapisy, ściśle związane z próbą przeżycia bombardowania miasta), by odnotować stan mostów nad Dunajem, fetor rozkładających się zwłok, a w ostatnim wierszu podsumować czas oblężenia słowami: „Peszt wyzwolony, Czemuż nie potrafię wydać z siebie okrzyku radości?” (Vas, 2000, 247). Wyraźnie widać więc, że węgierski twórca wybrał literaturę jako narzędzie utrwalania zapamiętanych obrazów, będąc przy tym świadomym licznych problemów i dylematów związanych z rejestrowaniem rzeczywistości, której tragizm przekracza możliwości artystycznego wyrazu.

Można postawić pytanie o motywacje, którymi kierował się Vas, wydając drukiem swój wojenny cykl. Podstawowe pobudki są stosunkowo łatwe do wskazania: miał głęboką potrzebę prywatnego rozliczenia i kierował się poczuciem historycznego obowiązku, ale przecież publikowanie omawianego cyklu nie odbywało się w korzystnych dla literatury warunkach. Kilka przykładów biograficznych pozwoli lepiej zobrazować postawę Vasa, który - jak wspominał jego przyjaciel, legendarny redaktor pisma „Holmi”, Pál Réz - bardzo surowo odnosił się do twórców zbyt oddanych polityce.

W rozmowie-rzece, Bokáig pezsgőben (hangos memoár) (2015) Réz przytacza dwie anegdoty z życia Vasa. Pierwsza w nich ma związek z niezwykle ważną inicjatywą, przygotowaniem jubileuszowego tomu z okazji sześćdziesiątych urodzin sekretarza generalnego Węgierskiej Partii Komunistycznej (MKP), Mátyása Rákosiego (1892-1971). Do współtworzenia tomu zostali zaproszeni wszyscy uznani pisarze węgierscy, prace 
redakcyjne wykonywał Vas (teksty poetyckie) i Réz (fragmenty prozatorskie). Poświęcone sekretarzowi teksty przesłali wszyscy liczący się twórcy, sprzyjający ideologii komunistycznej oraz pisarze niezależni, dokonano selekcji (zajmował się nią głównie Związek Pisarzy Węgierskich). Głównym kryterium doboru tekstów była poprawność polityczna, a teksty miały wskazywać i akcentować znaczenie dokonań Rákosiego w dziejach narodu. Ostatecznie w tomie wydano utwory wybitnych artystów, m.in. Zoltána Zelka, Tibora Déryego, Istvána Örkénya, Istvána Sőtéra, Tibora Cseresa, ale w tomie nie znalazł się wiersz Vasa, twórcy bezpośrednio zaangażowanego w pracę rządu. Réz nazwał tę antologię „marną”, ,pozbawioną jakiejkolwiek wartości literackiej" (Réz, 2015, 65-66):

\begin{abstract}
Z pewnością byli tacy, którzy wstydzili się udziału w tym projekcie. Ja też nie wspominam jej z radością, ale to oczywiste. Kiedyś zapytano mnie, co czułem, kiedy powierzono mi tę pracę, jaka była moja pierwsza reakcja? Cóż, nie przyszło mi do głowy, żeby odrzucić propozycję [...]. Nie powiedział, że coś wymyśli, że się rozchoruje, złamie nogę lub coś innego, ale że zrobi to do końca nudząc się i szydząc z tekstów [...]. Pamiętam, że Vas nie chciał figurować w tomie jako poeta, więc napisał koszmarnie zły wiersz [...]. Nie był on przesadnie tendencyjny, ale po prostu zły, a ponieważ nie mógł oceniać własnego tekstu, ja wyrzuciłem wiersz z antologii, dając negatywną ocenę. I dopisałem, że, niestety, wiersz Vasa jest zupełnie nieudany, rękopis wysłano więc do centrali partyjnej i tam też orzeczono, że to rzeczywiście zupełnie nieudany tekst i nie wydaliśmy go (Réz, 2015, 66-67).
\end{abstract}

Taktykę Vasa Réz określił jako „przebiegły unik”. Poeta podarł swój tekst i nie zamieścił go w żadnym ze swoich późniejszych tomów, więc właściwie zatarł ślady tej krótkiej propolitycznej aktywności poetyckiej. Podobnie zachował się Milán Füst, który zaproponował do tomu fragment swojego thumaczenia Króla Leara (Réz, 2015, 67). Z wiadomych względów ta propozycja została natychmiast odrzucona, a węgierski prozaik szczycił się tym, że nie odmówił partii, ale też nie dopisał się do listy artystów gotowych poświęcić część swojej sztuki komunizmowi.

Druga z anegdot dotyczy dnia wybuchu rewolucji październikowej w Budapeszcie w 1956 roku. Kiedy rozpoczęły się zamieszki i budapeszteńczycy zaczęli gromadzić się wokół pomnika Józefa Bema, by później przejść pod parlament, grupa blisko związanych ze sobą literatów (w tym Réz, a także Vas, Lajos Tóth) jadła obiad w restauracji Kulacs. 
Nagle wszedł Lajos Kamondy - wspomina Réz - i mówi, że studenci zorganizowali demonstrację, idą pod pomnik Bema [...]. Vas też tam z nami był i właśnie zamówił perliczkę. To było w „Kulacsu” niezwykłe, że można było tam zjeść perliczkę. Szybko zerwaliśmy się z miejsc, [...], a Vas oznajmił, że zaczeka, aż mu przyniosą obiad. Ktoś zapytał, czy perliczka obchodzi go bardziej niż rewolucja? Pomyślał chwilę i odparł: tak, znacznie bardziej. Perliczka jest ważniejsza od rewolucji (Réz, 2015, 91-92).

Z biografii Vasa wiemy, że poeta do końca życia dbał o zachowanie dystansu, a niechęć do impulsywnych reakcji na politykę miała silne umocowanie we wrodzonym sceptycyzmie i pragnieniu oddzielania sztuki od spraw państwowych, nawet wówczas, gdy osobiście był zaangażowany w pracę dla partii komunistycznej.

W jednym z najsłynniejszych wierszy, Óda a tegnapi asszonyokhoz (Oda do wczorajszych kobiet; Vas, 1960) Vas powołał do życia figurę kobiet, których życiorysy rozpięte są między dwoma reżimami: faszyzmem i komunizmem. Pierwszych mężów zamordowali naziści, a drudzy mężowie odsiadują wyroki w stalinowskich więzieniach. Chociaż w utworze można dostrzec wiele wątków autobiograficznych (np. odniesienie do losu bliskiej przyjaciółki, Fanni Gyarmati, żony Miklósa Radnótiego zestrzelonego do masowego grobu w Abda), wyraźnie pobrzmiewa w nim echo pokoleniowego głosu twórców. We wspomnieniach Dossier K. Imre Kertész pisał:

Komuniści, jak gdyby solidaryzując się z nazistowską przeszłością, ukryli wszystkie dokumenty: $\mathrm{z}$ czeluści bibliotek musiałem wydobywać niekompletne zazwyczaj materiały, a wydawane wówczas książki milczały o stronie przeszłości (Kertész, 2008, 9).

Vas, będąc wnikliwym obserwatorem rzeczywistości, postanowił rozliczyć się sam przed sobą z zapamiętanych obrazów. Do końca życia wracał do czasów II wojny, przytaczał poszczególne wydarzenia, odtwarzał z pamięci dialogi i analizy. Wtórne refleksje eseistyczne (zamieszczone w dwutomowej powieści Azután) nie miały już jednak takiej siły jak wierszowane relacje z cyklu Márciustól márciusig, który pozostaje do dzisiaj jednym z najważniejszych utworów podejmujących temat tragedii budapeszteńczyków i dowodzących wielkiej odwagi artystycznej Vasa, twórcy potrafiącego zamanifestować zupełne oddanie sztuce domagającej się prawdy i sprawiedliwości. 


\section{Literatura}

Fenyő, I. (1976). Vas István. Budapest: Akadémiai Kiadó.

Fenyves, K. (2010). Képzelt asszimiláció. Négy zsidó értelmiségi nemzedék önképe. Budapest: Corvina Kiadó.

Kálnoky, L. (1947). Vas István: Kettős örvény. „Vigília” nr 8, s. 508.

Kemény, S. (1987). Napló 1942-1944. Budapest: Magvető.

Kertész, I. (2008). Dossier K. Przeł. E. Sobolewska. Warszawa: W.A.B.

Köbányai, J. (2014). Szétszálazás és újraszövés. A Múlt és Jövö, a Nyugat és a modern zsidó kultúra megteremtése. Budapest: Múlt és Jövő Kiadó.

Lukács, G. (1999). Megjegyzések az irodalmi vitához. W: In memoriam Vas István. Óda az észhez. Red. P. Réz. Budapest: Nap Kiadó.

Márai, S. (2004). Dziennik (fragmenty). Przekł., oprac., przyp. i posł. T. Worowska. Warszawa: Czytelnik.

Ottlik, G. (1973). Szkoła na granicy. Przeł. T. Olszański. Warszawa: PIW.

Réz, P. (1999). Folyamatos jelen. Beszélgetés Réz Pállal - a tv-portréfilmjében. W: In memoriam Vas István. Óda az észhez. Budapest: Nap Kiadó, s. 5-25.

Réz, P. (2015). Bokáig pezsgöben (hangos memoár) a beszélgetötárs Parti Nagy Lajos. Budapest: Magvetö.

Sturm, L. (2017). Vas István. Budapest: Magyar Müvészeti Akadémia.

Vas, I. (1958). Naplójegyzetek. W: Évek és müvek. Budapest: Magvetö, s. 99-117.

Vas, I. (1979). Naplójegyezetek. W: Körül-belül. Budapest: Szépirodalmi Könyvkiadó, s. $129-141$.

Vas, I. (1987). Igen is, nem is. Esszék. Budapest: Szépirodalmi Könyvkiadó.

Vas, I. (1990). Azután. Budapest: Szépirodalmi Könyvkiadó, t. 1.

Vas, I. (1996). Ostromnapló. Przyp. opatrzyła K. Monostory. „Holmi” nr 4, s. 593-624.

Zimándi, P.I. (2015). Egy év története naplójegyzetekben. 1944. március 19. - 1945. március 17. Budapest: Magvető. 